\title{
Analysis and Countermeasure Research on Financial Risks of P2P Network Lending Platforms
}

\author{
Wei Wei \\ Wuhan University of Science and Technology \\ 329919815@qq.com
}

\begin{abstract}
Along with the arrival of P2P lending platforms, the financing demand of small-scale lending subject has been satisfied and the prosperous development of medium and smallsized enterprises has also been facilitated. However, the financial strength of P2P borrowers is generally not strong and the platform is confronted with large financial risk. Thus, the economic benefit it brings is insignificant. In this paper, the financial risks of P2P lending platform will be deeply analyzed. Besides, related suggestions for corresponding financial risks will be also proposed. The financial risks of P2P platform including capital fund risk, liquidity risk, asset quality risk and profit risk will be obtained through analysis by combining with the characteristics of financial risk of commercial bank and financial risk of P2P platform itself. Some measures such as extracting enough loan loss provision, strengthening liquidity management, looking for high quality customers, making impairment test for creditor's rights and improving financial risk management system need to be adopted to cope with according to these financial platforms.
\end{abstract}

Keywords-internet financial; P2P network lending; platform; financial risk

\section{INTRODUCTION}

PPdai is the first P2P network lending platform in China, was established in June, 2007. Through five years' gradual development, P2P network lending platform in China was developed at explosively accelerated speed from 2013 and increased to 1680 in 2014, an increase of $262 \%$, increased to 1861 in 2015 with trading volume of $9,823.05$ trillion, an increase of $288 \%$, and increased to 5877 by the end of 2016 . However, the number of platforms closed down and confronted with the problems was increased 3429. Among platforms confronted with problems, $\mathrm{P} 2 \mathrm{P}$ platforms mainly face "escaping" and "withdrawal difficulty". According to the data released by "Online Lending House", it shows that the platforms facing "escaping" and "withdrawal difficulty" account for $61 \%$ and $38 \%$ among those with problems. To be specific, the platforms facing "escaping" are classified into two types: namely the "scam" platforms, the purpose of whose establishment is to gain the principal of the investors by cheating. When the financing reaches certain target amount, these platforms escape with the funds, and those escaping helplessly due to the capital chain rupture brought by bad management. In general, the subjective purpose of such platforms is to continue operation. However, along with the difficulty in turnover of capital due to bad subjective operation, the investors are usually faced up with "withdrawal difficulty". The platforms facing "withdrawal difficulty" indicates those are confronted with shortage of funds for the operation of platform and fail in withdrawal due to improper operation and or monitoring of the platform.

In 2016, CBRC, MIIT, Ministry of Public Security and State Internet Information Office jointly released "Temporary Management Methods for Activities of Network Lending Information Intermediaries", which defines P2P as information intermediary and connotations of network lending. The network lending institution should raise funds for it or in a disguised way and should not provide guarantee for the lender or promise guaranteed principle and interested. The network lending institutions provide services including information collection, information release, credit assessment, information interaction and credit \& loan matching for lenders and borrowers by making use of internet as the main channel. P2P network lending platforms are reorganized with remarkable effect obtained. Gradual strengthening of external monitoring makes P2P industry march forward in normal and standard way. More importantly, P2P network platform should strengthen management of financial risk internally. There is lack of strict and systematic theoretical basis for financial risk identification, measurement and prevention of $\mathrm{P} 2 \mathrm{P}$ network lending platforms in China. The practitioners and related research workers don't pay enough attentions to the financial risks. In this paper, rational suggestions for financial risk management of $\mathrm{P} 2 \mathrm{P}$ network lending platforms in China are proposed through analysis on financial risks of $\mathrm{P} 2 \mathrm{P}$ network lending platforms in China from the perspective of platform.

\section{OPERATION MODE OF P2P NETWORK LENDING PLATFORM}

There are the following modes of $\mathrm{P} 2 \mathrm{P}$ in the rapid development in China.

\section{A. Pure Online Mode}

This kind of mode is also known as pure mediator pattern, the characteristic of which is platform is just as the mediator of financiers and investors, the platform itself has no money involved, is not directly involved in the loan or investment and is not as a creditor or debtor of either party [1]. In the pure online mode, loan default risk is bore by the lender and the platform does not undertake liability for loan default. 


\section{B. Click-and-Mortar}

Such mode network provides only information about transaction, and specific transaction procedures are performed by P2P network lending platform and customers face to face. This mode requires that platform needs to evaluate credit status offline of financing side after the financing side raises the financing requirement. Only passing the offline credit assessment can online borrowing be allowed. The platform will make a online sale of this loan, and this process is similar to pure platform model.

\section{Principle and Interest Guarantee Mode}

Principle and interest guarantee mode means that the platform provides the guarantee of principle and interest to the lender. However, most platforms have neither clear explanation about the source of deposit and risk petty cash established as well as the use condition and dynamic range of risk petty cash, nor the subject of liability undertaking risk as well as whether the platform provides guarantee funds in the limit of risk petty cash.

\section{Debenture Transfer Mode}

Debenture transfer mode is not the borrowing in traditional meaning. The debtors and creditors don't sign a contract of claims and debts directly, instead, a third party, closely linked to the platform, makes the first loans and then transfers the claims to investors. In this mode, network lending platform will actively cooperate with offline traditional finance company in order to better match the fund demands of financiers and investors and to rapidly develop customers as well as increase market share in a short time.

\section{FINANCIAL RISKS OF P2P NETWORK LENDING PLATFORM IN CHINA}

Corporation financial risk in indicates the risk that the investor's prospective earning is reduced due to the company's possible loss of debt paying ability caused by irrational financial structure and improper financing of the company. The financial risk of P2P network lending platform indicates the capital of the platform is in shortage and even broken during operation of the platform. As financial institution, the financial risk of $\mathrm{P} 2 \mathrm{P}$ network lending platform also has certain peculiarity.

Though P2P network lending platform is an information intermediary, the qualification of lender and borrower, authenticity of information and legality of financing item should still be verified. The risk of the platform is related to lender and investor. The platform faces high-risk non-high net worth clients. In addition, comprehensive interest rate of P2P network lending is very high. If the fund can be obtained from commercial bank or micro-loan company, the lender general will not choose network lending platform. However, the platform should accept such risk to obtain benefit. In conclusion, the typical characteristic of the network lending platform is high risk and benefit. Besides, P2P network lending platform is also characterized by long tail. Long tail theory, proposed by Chris Anderson, the editor-in-chief of American magazine "Ligature", indicates the market jointly shared by the products with sluggish demand or bad sales volume can be equal and even larger to that by few hot-sale products. That is, numerous small markets get together to generate market energy that can be matched with that of the mainstream markets. P2P financing service features low circulation cost and high fixed investment cost in the earlier stage. However, the marginal cost is reduced along with the increase in amount of service. There are enormous and diversified medium and small-sized enterprises in China. The supply of P2P financing fund is sufficient, having the condition for "The Economics of Abundance" and also satisfying individual investment demand. Therefore, P2P financing platform also provides diversified pathway for the enterprise to raise funds and also constitutes the long tail in for corporate financing market except bank loan financing.

P2P network lending platforms and commercial banks belong to the financial institutions engaged in lending business. There has been mature research on financial risks of commercial banks. There is similarity between concrete manifestation form of financial risk of P2P network lending platforms in China and traditional commercial banks [2]. However, there are also many differences. By combining the characteristics of commercial banks and $\mathrm{P} 2 \mathrm{P}$ platforms, the financial risks of $\mathrm{P} 2 \mathrm{P}$ network lending platform are classified into following categories:

\section{A. Capital fund risk}

Capital risk indicates the risk that there is lack of enough funds for the borrower's possible breach of contract to guarantee the principal and interest of the investor due to the few existing proprietary fund of P2P network lending platforms. The fund of principal and interest guarantee commitment executed by using P2P network lending platform is mainly from the risk reserve account of the platform and paid-up capital of the companies owned by the platform. Fund risk indicates the risk that $\mathrm{P} 2 \mathrm{P}$ lending platform will generate a lot of fund precipitations and capital embezzlement is easily caused and even absconding with money occur, thus bringing about fund loss to the lender.

\section{B. Liquidity risk}

Liquidity risk mainly indicates that the principal and interest cannot be repaid to the investor on time due to the insufficient liquidity funds during operation of the platform or the possibility of sudden investor's disinvestment tide of investor cannot be coped with [3]. Liquidity represents the capacity that one platform can repay the principal and interest on time and cope with sporadic fund demand. If one platform can obtain the cash satisfying the fund demand at rational cost, the liquidity of the platform can be regarded to be relatively sufficient. Otherwise, the corresponding problems might be caused. Liquidity risk is a typical risk type of P2P network lending platform. It also belongs to the range of financial risk. All financial institutions also create risk while creating liquidity. 
The reason for causing liquidity risk refer to the irrational "demolition standard" behavior of the platform. Demolition standard mainly includes two situations. Firstly, period is decomposed. That is, single long-term claim is decomposed into many short-term claims. Secondly, the amount is decomposed. To attract more investors at the very beginning, many platforms decompose one object into many small ones. Especially, large-amount claim is decomposed into many small-amount claims, thus, dead debt is caused easier and liquidity risk can be caused.

\section{Asset quality risk}

Asset quality risk indicates the risk caused by nonperforming loan when $\mathrm{P} 2 \mathrm{P}$ network lending platform is engaged in loan business. The borrowers of P2P network lending platforms in China are mainly those with low credit rating and who cannot obtain loan from the bank, so all loans of P2P network lending platform should be regarded as the non-performing loans according to the judgment standard of commercial bank for non-performing loan. Many large-scale platforms neglect asset quality due to the pursuit of large asset scale. Their risk control system and technology is relatively weak and even not available. When such asset enters the repayment period, the default rate of asset with bad quality will be increased, thus the asset quality risk will be caused.

\section{Profit risk}

Profit risk indicates the risk that the platform cannot obtain enough profits and even suffer from asset loss due to some subjective factors during operation of $\mathrm{P} 2 \mathrm{P}$ network lending platforms. P2P network lending platform is the profit organization. Only by guaranteeing the profitability of the platform could be its financial safety guaranteed. At the present there is lack of transparence for overall financial information of P2P network lending platform. As for the financial data released by the platform, its authenticity usually cannot be proved. Besides, sensitive financial data including return on asset, earnings per share and interest income will not be released.

\section{SUGGESTIONS AND COUNTERMEASURES FOR FINANCIAL RISKS OF P2P LENDING PLATFORMS IN CHINA}

The development of P2P lending industry still remains to be standardized. To always keep competitive and obtain longterm and stable development, the corresponding measures should be taken to prevent financial risks.

\section{A. Withdraw risk reserve fund}

To provide guarantee for the investor, P2P network lending platforms in China should allocate sufficient risk reserve funds [4]. It is better to have definite calculation methods for risk reserve funds and it is necessary to have risk reserve fund account under custody of the bank or third party to guarantee its authenticity and safety [5]. If possible, it is better to provide inquiry link so that the borrower and investor can inquire into the change in risk reserve fund in real time.
The lender shall open independent bank account for his fund flow. It is necessary to define the consigning accountability for the stock of fund formed on the way and have it under custody of the bank or independent third party to prevent network lending intermediary from embezzling it or escaping with it. In Feb., 2017, CBRC officially released "Guidance for Deposit Business of Network Lending Fund" and also explained third-party deposit work deployment and requirements for building client's funds, realizing independent account management of client's fund and proprietary funds of intermediary in network lending information and preventing embezzlement risk of network lending fund. Firstly, it is necessary to abide by orientation of intermediary service in credit and loan to differentiate proprietary account and lender's and borrower's fund accounts to guarantee independent account management and accounting to build solid "fire wall". As for lender's fund account, intermediary in network loan shall independently open account with fixed purpose to clearly calculate cash flow and benefit. The lender's fund is transferred to the lender immediately after it is available. The borrower repays the amount to the lender after repaying the principal and interest.

\section{B. Strengthen liquidity management}

Demolition standard should not be implemented easily. Even in case of special circumstance, the platform also cannot actively intervene in or seduce clients to accept offer. The best method is that the platform shall build perfect secondary market for credit assignment at its website so that the investors can transfer the platform loan in case of urgent demand for funds so as to reduce the liquidity risk of the platform. In addition, entity mortgage loan can be executed especially the auto loan, rapid circulation of funds can be realized. With strong cashability, the liquidity risk can be reduced.

\section{Look for superior clients and implement devaluation test for the creditor's rights}

Network lending platform faces "secondary" clients screened out by the bank, based on which the asset quality of network lending industry directly decides the safety of the platform. The objects for the platform in the future are superior borrowers. The obtaining and screening of superior assets is the first threshold of risk control of P2P lending industry and also the basis for follow-up risk control and stable operation of the platform. Besides, network lending platform shall implement devaluation test for the creditor's rights not assigned at regular interval [6]. When recoverable amount of creditor's rights is lower than book value, it is necessary to calculate diminution in value to prevent exaggerated increase in asset and benefits. Because the risk of network lending platform is higher, there is large uncertainty during the period of existence of borrower's creditor's right. It is necessary to follow prudence principle for the creditor's rights not assigned to make professional judgment for the uncertainty and implement devaluation test regularly. During this process, the borrower can be required to provide certification for using the fund to monitor the fund flow. 


\section{Improve financial risk management system}

The operator of $\mathrm{P} 2 \mathrm{P}$ network lending platforms in china shall strengthen monitoring of their employees, attach importance to training the skills of the financial workers and improve financial risk management system construction of the platform. The business quality and professional capacity of platform's employees especially the financial workers should be improved. They should have the concept for preventing and evading financial risks and fully recognize the existence and danger of financial risk. Only by doing in this way, the potential financial risks could be immediately found during the work at ordinary and also can be coped with correctly.

\section{CONCLUSIONS}

P2P industry in China effectively provides service for clients that cannot be covered by many formal financial institutions and also satisfies the demands of small amount fund and that of small amount for convenience. However, there have been lots of risks generated during the process of accelerated development. It is meaningful to externally strengthen external monitoring to realize continuous sound development of P2P industry. In the meantime, the platform also should attach importance to the financial risk.

Through analysis, it is concluded that the financial risks of P2P network lending platforms in China mainly include capital fund risk, liquidity risk, asset quality risk and profit risk. It is necessary to extract sufficient risk reserve funds, strengthen liquidity management, search for superior clients and have devaluation test for the creditor's rights at regular interval and improve financial risk management system. By supporting the development of network lending intermediaries with good reputation, sufficient funds and operation standards and protecting joint benefits of all participants, P2P network lending platform can better serve real and micro economy.

\section{REFERENCES}

[1] Ye Xiangrong. Model of P2P loan risk and regulation [J] .Journal of Financial Supervision, 2014, (03): 71-82.

[2] Zhang Mengjun. Internet financial development status and financial risk analysis - P2P industry Hongling venture capital firm as an example [J] .Automatic business assets and finance, 2017, (16): 85-86.

[3] Division Man Man. P2P network loan financial risk control [D]. Southwest University of Finance and Economics, 2016.

[4] Wang Hao. China P2P network lending platform financial risk research [D]. Anhui University, 2016.

[5] Xu policy. China's P2P risk and financial regulatory mechanism [J]. Financial Accounting, 2014, 03: 26-30.

[6] Wang Xue (Wang Le), Bai Bing. P2P loan platform financial risk control research [J]. Green Accounting, 2017,01: 6-11. 